\title{
Effect of Yeast and Ascorbic Acid Application on Growth and Fruiting of Williams Banana Plants
}

\section{El-Salhy, A.M.; A.H. Abd El-Aal; A.A.E. Silem and A.M.H. Shabib}

${ }^{1}$ Pomology Department, Fac. Agric, Assiut University

${ }^{2}$ Horticulture Department, Fac. Agric, Al-Azhar University, Assiut Branch.

Received on: 28/3/2019

Accepted for publication on: 5/3/2019

\section{Abstract}

This study was conducted during two successive seasons (2016/2017 first ratoon and 2017/2018 second ratoon) of Williams banana plants. The plants grown in a private banana orchard, where clay loam soil under flood irrigation system, at $3.5 \times 3.5 \mathrm{~m}$ apart located at Nakada district, Quena Governorate, Egypt. Forty eight stools each containing three plants were chosen to evaluate the effect of yeast applied as soil drench and spraying ascorbic acid (V.C) on growth, yield and fruit quality. These treatments were arranged in a randomized complete block design in split plot arrangement with three replicates. The obtained results could be summarized as follows. Ascorbic acid spraying significantly increased the length and circumference of pseudostem, leaf area and total leaf area/plant as well as percentage of $\mathrm{N}, \mathrm{P}$ and $\mathrm{K}$ of leaves compared to unsprayed ones. Also, these treatments significantly increased the yield components and improved the fruit quality compared to unsprayed ones. Yeast application was very effective in enhancing all growth aspects, yield and fruit characteristics compared to untreated ones.

All combinations of ascorbic acid spraying on the yeast treated plants resulted in a significant increament in all growth aspects, yield components and fruit quality as compared to check treatments. The best results regarding the growth and fruiting were obtained with ascorbic acid spraying (at $200 \mathrm{ppm}$ ) accompanied with yeast application (at $40 \mathrm{~g} / \mathrm{plant}$ ) compared to other tested treatments.

It is evident from the foregoing results that the application yeast at 40 $\mathrm{g} / \mathrm{plant}$ and ascorbic acid at $200 \mathrm{ppm}$ application four times during growth season (April, June, August \& October), singly or in combination improved the growth and yield of Williams banana plants.

Keywords: Banana, Yeast, Anti-oxidants, Yield, Fruit quality.

\section{Introduction}

Banana (Musa sp.) is the fourth largest fruit crop in the world, following grapes, citrus and apple. It plays an important role in tropical economics as cash export and as complementary food in local sets. It have a great economic importance as one of the most popular fruits in Egypt for its high nutritive value, cheap source of energy i.e. high starch content vita- mins and other minerals with traces of fat. Banana fruits may be consumed either fresh or processed into juice, banana puree, flour, dried catsup, ships, alcohol, vinegar, beers, spirits and as a source of carbohydrate (Abdel-Moniem-Eman et al., 2008). The total area of banana increased to 79857 feddan produced 1314177 tons with average of 20.54 
ton/feddan according to M.A.L.R. (2016).

So, the major problems facing banana growers are the high costs of excessive manufactured fertilizers needs. Besides, these chemical fertilizers are considered as air, soil and water polluting agents during their production and utilization (AbdelMoniem-Eman et al., 2008; Kuttimani et al., 2013 and Abdel-Hafiz et al., 2016).

Williams cv. is considered to be one of the important tropical fruits successfully grown under Egypt climatic conditions. Nowadays, many efforts have been established for finding out the best horticultural practices that enhancing yield and fruit quality (Saleh, 1996; Abdel-Hafiz et al., 2016).

Clean cultivation is greatly achieved by using yeast. It contains highe amounts of IAA, cytokinins, proteins, amino acids as Arginine, Histidine, Isoleiucine, Leucine, Lysine, Methionine, Cysteine, Phenylalanine, Tyrosine, Serine, Valine, Threonine, Tryptophan, vitamins namely vitamins $B$, minerals such as $\mathrm{N}, \mathrm{P}$ and $\mathrm{K}$ according to (Abou-Zaid, 1984 and Barnett et al. 1990).

Previous studies showed that using yeast Abd El-Rahman (2005), Badran and Mohamed (2009), Merwad (2011), Mahmoud, (2012), Abdel-Rahman and Mansour (2015) and Roshdy (2016) was very potent in stimulating growth and nutritional status of the fruit trees as well as promoting yield and fruit quality.

Recently, it was suggested that vitamins participate in plant growth and development indirectly by enhancing the endogenous levels of various growth factors such as cytokinins and gibberellins. Most vitamins are synthesized in the leaves and translocated in the phloem to the other organs. These studies indicated that various physiological process such as nutrient uptakes, absorption of water, translocation of organic foods, building of natural hormones, respiration, photosynthesis as well as chlorophyll and protein synthesis depended more or less on the availability of vitamins (Samiullah et al., 1988). Ascorbic acid has an auxinic action and synergistic effect on flowering and fruiting of fruit trees as well as, ascorbic acid is a natural and safety used instead of synthetic auxins. Six sprays of $100 \mathrm{ppm}$ ascorbic acid were very effective in improving the yield of banana plants (Alscher et al., 1997; Ahmed et al., 2003; Mostafa, 2004; Abdel-Rahman, 2005; Marwad, 2011 and El-Baz et al., 2016).

This study was established for examine the effect of single or combined applications of yeast and ascorbic acid on growth aspects, nutritional status of the plants, yield and fruit quality of Williams banana plants grown under Qena Governorate climatic conditions.

\section{Materials and Methods}

This study was conducted during two successive seasons (2016/2017 first ratoon and 2017/2018 second ratoon) on Williams banana plants grown in clay loam soil under flood irrigation system in a private banana orchard located at Nakada district, Qena Governorate, at $3.5 \times 3.5 \mathrm{~m}$ apart. Soil analysis was done according to Wilde et al. (1985) and the obtained data are 
shown in Table (1). Forty eight stools/(mat), each containing three plants of Williams cultivar were chosen to evaluate the effect of yeast and ascorbic acid (Vit. C) on vegetative growth, yield and fruit quality of the tested banana cv.

The experiment contained two factors, was set a completely randomized block design split plot arrangement with three replicates one stool each. The two factors involved this experiment and their level were arranged in the experimental plots as follows:

The first factor (A) which occupied the main plots comprised from the four yeast application, as follow:
1 - Control ( 0.0 yeast).
2 - Yeast at $20 \mathrm{~g} /$ plant.
3 - Yeast at $40 \mathrm{~g} /$ plant
4- Yeast at $60 \mathrm{~g} /$ plant

Table 1. Analysis of the tested orchard soil.

\begin{tabular}{|l|c|l|c|}
\hline \multicolumn{1}{|c|}{ Characters } & Values & \multicolumn{1}{|c|}{ Characters } & Values \\
\hline Particle size distribution: & Total N \% (5. & 0.16 \\
Sand \% & 15.40 & Available P (pm, Olsen) & 4.22 \\
Silt \% & 50.50 & Available K (ppm, ammonium acetate) & 310 \\
Clay \% & 34.10 & Available S (ppm) & 3.11 \\
Texture & Silty clay & Available EDTA extractable micronutrients (ppm) & \\
PH $(1: 2.5$ extract) & 7.29 & Zn & 11.49 \\
EC $(1: 2.5$ extract) & 0.74 & Fe & 9.11 \\
$\mathrm{mmos} / 1 \mathrm{~cm} / 25^{\circ} \mathrm{C}$ & & & \\
$\mathrm{O} . \mathrm{M} \%$ & 1.73 & $\mathrm{Mn}$ & 10.1 \\
$\mathrm{CaCo} \%$ & 1.80 & $\mathrm{Cu}$ & 1.05 \\
\hline
\end{tabular}

The second factor (B) which occupied the sub-plots consisted from the four ascorbic acid, as follows:

1- Control (foliar spray with water).

2- Foliar spray with ascorbic acid at $100 \mathrm{ppm}$.

3- Foliar spray with ascorbic acid at $200 \mathrm{ppm}$.

4- Foliar spray with ascorbic acid at $300 \mathrm{ppm}$.

Therefore, the experiment included sixteen treatment, each treatment was replicated three time, one stool per each.

Yeast as a biofertilizer was activated before application by using sugar solution at $5 \%$. Solution ascorbic acid was water based. Both yeast and ascorbic acid applied four times on April, June, August and October.
Other horticulture practices such as irrigation, fertilization and pest control were carried out as usual. The following parameters were measured on selected plants during the two growth seasons.

\section{1- Vegetative characteristics:}

After the emergence of the inflorescence at the $3^{\text {rd }}$ week of July for both the first and second ratoons, the following parameters were studied, vegetative characteristics included pseudostem length $(\mathrm{cm})$ and its circumference diameter in $(\mathrm{cm})$, number of green leaves per plant at bunch shooting and leaf area $\left(\mathrm{m}^{2}\right)$ using the third full sized leaves according to Murry (1960) and calculated as follows:

Leaf area $\left(\mathrm{m}^{2}\right)=$ Length $\mathrm{x}$ Width $\mathrm{x} 0.8$ 


\section{2- Leaf mineral contents:}

Leaf samples were taken from the third upper leaf from the top of the plant after bunch shooting in September of each season. A sample of $10 \times 10 \mathrm{~cm}$ from the middle part of the leaf blade was used as recommended by Hewitt (1955). Samples were oven dried at $70^{\circ} \mathrm{C}$ and digested. The clear digestion was quantitatively transferred to $100 \mathrm{ml}$ volumetric flask. In this solution, the following nutrients were determined according to Wilde et al. (1995).

a) Total $\mathrm{N}$ was determined by using micro-kjeldahl method.

b) Phosphorus was determined by using Olsen method.

c) Potassium was determined by using flame photometer.

\section{Yield and fruit quality}

Bunches of banana were picked during the common harvest date during the period from November to January in both seasons which the bunch (or fruits) were suitable (when fingers attained full mature stage) for harvesting. The artificial ripening for bunches was carried out, then the fruit quality was evaluated.

Bunch weight and two hands were taken from the base, middle and distal end of each bunch as sample for each replicate.

Hand weight $(\mathrm{kg})$, finger weight (g) and pulp \% were recorded.

Percentage of total soluble solids, total and reducing sugars and total acidity (as malic acid/100 g pulp) was determined according to A.O.A.C. (1990).

The obtained data were subjected to statistical analysis of variance were compared using L.S.D. test at $5 \%$ level according to Gomez and
Gomez (1984) and Mead et al. (1993).

\section{Results}

1- Effect of yeast and ascorbic acid application on vegetative growth and percentage of $N, P$ and $K$ in leaves:

Data presented in Tables (2 to 5 ) show the effect of yeast and ascorbic acid application and their interaction on length and circumference of pseudostem and number of green leaves/plant as well as leaf area, total leaves area/plant and percentage of $\mathrm{N}, \mathrm{P}$ and $\mathrm{K}$ in leaves of Williams banana plants during 2016/2017 and $2017 / 2018$ seasons. It is obvious from the data that the results took similar trend during the two studied seasons. Such data showed that application of yeast significantly increased such traits compared to untreated ones. The promotion effect on such growth traits was associated with increasing the yeast from 0.0 to $60 \mathrm{~g} / \mathrm{plant}$. Moreover, there was insignificant difference in these studied traits due to fertilize with yeast at 40 as compared with $60 \mathrm{~g} /$ plant.

In relation to the effect of ascorbic acid spraying, data indicated that all studied pseudostem growth and leaf traits as well as leaf contents of $\mathrm{N}, \mathrm{P}$ and $\mathrm{K}$ were significantly increased compared to unsprayed ones. The highest values of these growth traits were recorded due to spray ascorbic acid at $300 \mathrm{ppm}$. No significant differences in these growth characters for ascorbic acid spraying at 200 or $300 \mathrm{ppm}$ were recorded.

As interaction, all ascorbic acid spraying in the presence of yeast application significantly increased these growth traits compared to untreated 
ones. Spraying ascorbic acid on yeast treated plants gave the highest growth traits values, whereas, untreated plants recorded the least ones.

The recorded total leaf area/plant was $(20.88,23.32,26.17 \&$ $\left.27.21 \mathrm{~m}^{2}\right)$ and $(20.57,22.83,24.69 \&$ $26.39 \mathrm{~m}^{2}$ ) due to apply yeast at 0,20 , 40 and $60 \mathrm{~g} /$ plant during the two studied seasons, respectively. As well as such trait was $(19.48,23.19,26.07$ $\left.\& 28.85 \mathrm{~m}^{2}\right)$ and $(19.42,22.42,25.62$ \& $27.04 \mathrm{~m}^{2}$ ) due to spray ascorbic acid at $0.0,100,200$ and $300 \mathrm{ppm}$ during the two studied seasons, respectively. Moreover, the total leaf area/plant was $\left(27.59 \& 26.56 \mathrm{~m}^{2}\right)$ due to combine of yeast at $40 \mathrm{~g} / \mathrm{plant}$ along ascorbic acid at $200 \mathrm{ppm}$, against $\left(15.59 \& 16.20 \mathrm{~m}^{2}\right)$ on untreated plant. Then, the increment percentage attained $(25.34,33.82$ \& $76.97 \%)$ and $(20.03,31.19$ \& $63.95 \%$ ) due to yeast at $40 \mathrm{~g} / \mathrm{plant}$, ascorbic acid at $200 \mathrm{ppm}$ and combined of them compared to check treatment during the two studied seasons, respectively. Therefore, using combination of yeast and ascorbic acid significantly increased the total leaf surface area, nutritional status and vegetative growth of plants than use yeast or ascorbic acid individual.

\section{2- Effects on bunch weight:}

It is clear from the data in Table (5) that application of Williams banana plants with yeast or ascorbic acid singly or in combination significantly increased the bunch weight and hand weight compared to untreated ones (check treatment). The promotion on the bunch weight and hand weight was associated with increasing doses of yeast from 0.0 to 60 $\mathrm{g} /$ plant or ascorbic acid from 0.0 to
$300 \mathrm{ppm}$. Yeast and ascorbic acid in combination significantly increased the bunch weight and hand weight rather than using yeast or ascorbic acid alone. In addition, there was insignificantly difference in the bunch weight or hand weight due to increase the yeast doses from 40 to $60 \mathrm{~g} /$ plant, as well as to increase ascorbic acid spraying from 200 to $300 \mathrm{ppm}$. The heaviest weight of bunch and hand were recorded on the plants that treated by yeast at $60 \mathrm{~g} / \mathrm{plant}$ combined with ascorbic acid at $300 \mathrm{ppm}$. The recorded bunch weight was $(18.6,21.4,22.9 \& 23.2 \mathrm{~kg})$ and $(26.1,29.5,33.1 \& 33.8 \mathrm{~kg})$ due to apply yeast at $0.0,20,40$ and 60 $\mathrm{g} / \mathrm{plant}$ during the two studied seasons, respectively. The increment percentage of bunch weight was attained $(15.05,23.12 \& 24.73 \%)$ and $(13.03,26.82 \& 29.50 \%)$ due to use yeast at 20,40 or $60 \mathrm{~g} / \mathrm{plant}$ compared to yeast at 0.0 during the two studied seasons, respectively. As well as, the bunch weight was $(20.2,21.5$, $22.0 \& 22.4 \mathrm{~kg})$ and $(27.4,30.5,32.0$ \& $32.7 \mathrm{~kg}$ ) due to ascorbic acid at $0.0,100,200$ and $300 \mathrm{ppm}$ during the two studied seasons, respectively. The increment percentage of bunch weight attained $(6.44,8.91 \& 18.00)$ and $(11.31,16.79 \& 19.34 \%)$ due to spray ascorbic acid at 100, 200 and $300 \mathrm{ppm}$ compared to unsprayed ones during the two studied seasons, respectively. Moreover, the bunch weight was $(23.4 \& 34.7 \mathrm{~kg})$ due to combine of yeast at $40 \mathrm{~g} /$ plant with ascorbic acid at $200 \mathrm{ppm}$, against $(16.8 \& 23.2 \mathrm{~kg})$ on untreated plants during the two studied seasons, respectively. Thus, the increment percentage was (39.29 \& 49.57\%) due to 
combine of yeast and ascorbic acid compared to untreated ones, during the two studied seasons, respectively. So, use combination of yeast and ascorbic acid significantly increased the yield than use yeast or ascorbic acid alone.

\section{3- Effects on fruit quality:}

It is evident from the data in Tables (6 to 9) that using yeast or ascorbic cid singly or in combination significantly improved fruit quality in terms of increasing finger weight, pulp \%, T.S.S.\% and sugar contents and decreasing the total acidity compared to untreated one. Moreover, using combination of yeast and ascorbic acid significantly increased the fruit traits than used yeast are ascorbic acid only. 
Doi: 10.21608/ajas.2019.41262

El-Salhy, et al., 2019

http://ajas.journals.ekb.eg/ 
The promotion in fruit quality was associated with increasing doses of yeast or ascorbic acid used. Increasing the doses of yeast from 40 to $60 \mathrm{~g} / \mathrm{plant}$, as well as ascorbic acid from 200 to $300 \mathrm{ppm}$ failed to significantly improved the fruit quality.

The recorded finger weight was $(95.3,108.0,115.0 \& 117.3 \mathrm{~g})$ and (101.3, 114.1, $124.4 \& 127.8 \mathrm{~g})$, as well as $(102.4,107.8,111.9 \& 113.4)$ and $(105.5,116.2,121.7 \& 124.2 \mathrm{~g})$ due to yeast at $0.0,20,40 \& 60$ $\mathrm{g} / \mathrm{plant}$, as well as ascorbic acid at $0.0,100,200 \& 300 \mathrm{ppm}$, during the two studied seasons, respectively. The corresponding TSS\% was (18.0, $19.1,19.4 \& 19.7 \%)$ and $(17.6,18.7$, $19.0 \& 19.3 \%)$, as well as $(18.2,19.0$, $19.5 \& 19.5 \%)$ and $(17.8,18.6,19.0$ $\& 19.2 \%$ ) during the two studied seasons, respectively. Hence, the increment percentage of finger weight attained $(13.33,20.67 \& 23.08 \%)$ and $(12.64,22.80 \& 26.16 \%)$, as well as (5.27, 9.28 \& 10.74\%) and (10.14, $15.36 \& 17.73 \%$ ) due to yeast at 20 , 40 or $60 \mathrm{~g} /$ plant, as well as ascorbic acid at 100,200 or 300 ppm compared to untreated ones during the two studied seasons, respectively.

The obtained finger weight was $(118.4 \& 129.7 \mathrm{~g})$ and TSS $(19.8$ \& $19.3 \%$ ) due to combination of yeast at $40 \mathrm{~g} /$ plant and ascorbic acid at 200 ppm during the two studied seasons, respectively. The corresponding values of finger weight $(86.5 \& 90.6 \mathrm{~g})$ and TSS (16.8 \& 16.3\%) on untreated plants during the two studied seasons, respectively. Hence, the increment percentage of finger weight attained $(36.88 \& 43.16 \%)$ and TSS (17.86 \& $18.40 \%$ ) due to combination of yeast at $40 \mathrm{~g} / \mathrm{plant}$ along ascorbic acid at
$200 \mathrm{ppm}$ compared to untreated ones during the two studied seasons, respectively.

Hence, the cost wise evaluation of the application of yeast at 40 $\mathrm{g} / \mathrm{plant}$ and ascorbic acid at $200 \mathrm{ppm}$ four times. Such appliction program is very important for the production of banana fruits, since the improve of the fruit quality induce an increase in packable yield.

\section{Discussion}

Clean cultivation is greatly achieved by using yeast (Saccarmyces cerevisae). The higher positive effects of yeast on growth and fruiting of fruit crops might be ascribed to its higher content of IAA, cytokinins, amino acids, minerals, nucleic acid, glutathione, lecithine, enzymes, coenzymes and vitamins B. Also, it is essential for the synthesis of amino lenulinic acid (AA) and protoprophyrin the precursor of chlorophylls and in activating photosynthesis through enhancing the release of carbon dioxide (Abou-Zaid, 1984 and Barnett et al., 1990).

Such finding was surely reflected on enhancing cell division and cell elongation which led to stimulate growth characters, advance of flowering, increase yield and improve fruit quality.

The promoting effect of yeast on growth and yield of Williams banana was confirmed by the results of Ebrahiem et al. (2000), Moustafa and El- Hosseiny (2001), Gobara (2004), Mostafa (2004), Abd El-MottyElham et al. (2010), Abd-El-Aal et al. (2012), Mahmoud (2012), Ahmed et al. (2013) on Mango, Abdel-Rahman and Mansour (2015) and Roshdy (2016). 
The promoting effect of growth traits, yield and fruit quality due to spraying of ascorbic acid might be attributed to its role in enhancing the endogenous levels of various growth factors such as cytokinins and gibberellins. In addition, it has important role in physiological process such as absorption of water, nutrient uptakes, building of natural hormones and photosynthesis as well as carbohydrate and protein synthesis. Moreover, ascorbic acid have catch all free redicals produced during plant metabolism, hence increasing plant resistance to stress (Samiullah et al., 1988; Elade, 1992; Alscher et al., 1997 and Ragab, 2002).

The above mentioned findings are in accordance with those obtained by Samiullah (1988), Ahmed et al. (2003), Mostafa (2004), AbdelRahman (2005), Merwad (2011) and El-Baz et al. (2016). They revealed that some vitamins foliar spray enhanced the growth, nutritional status and improved the yield and fruit quality of banana plants.

\section{Conclusion}

The best results with regard to vegetative growth and nutrition status as well as yield and fruit quality of Williams banana were observed due to treating the plants with four sprays of yeast at $40 \mathrm{~g} / \mathrm{plant}$ besides ascorbic acid at 200 ppm during the growth seasons, at April, June, August and October.

\section{References}

A.O.A.C. (1990). Association of Official Agricultural Analytical Chemists. Official Methods of Analysis. $15^{\text {th }}$ ed. Washington, DC, USA.

Abd El- Motty-Elham, Z., M.F.M. Shahin, M.H. El- Shiekh and M.M.M. Abd El- Migeed (2010). Effect of
Algae extract and yeast application on growth, nutritional status, yield and fruit quality of Keitte mango trees. Agric. Biol. J., N Am. 2(3): 421-429.

Abd El-Aal, A.M.K.; F.F. Ahmed and Kh.M.H. Mahmoud (2012). Partial replacement of chemical $\mathrm{N}$ fertilizers in Balady mandarin orchards through application of extracts of yeast, seaweed and farmyard manure. Minia J. of Agric. Res. \& Develop. 32(1): 129-148.

Abd El-Rahman, M.M.A. (2005). Influence of varying number of ratoons as well as some antioxidants and biofertilization treatments on growth and fruiting of Grand Naine banana growth under middle Egypt conditions. M.Sc. Thesis Fac. of Agric.Minia Univ. Egypt.

Abdel-Hafiz, G.; H.A. Abdel-Galil, Kamelia, I.A. Amin and R.A. Ibrahim (2016). Using the organic and bio-fertilizers as a partial substitute for mineral-N in Williams banana orchards. Assiut J. Agric. Sci., 47 (3): 34-46.

Abdel-Monem-Eman, A.; A.S.E. AbdAllah and M.A. Ahmed (2008). The combined effect of some organic manures, mineral $\mathrm{N}$ fertilizers and Algal cells extract on yield and fruit quality of Williams Banana plants. American Eurasian J. Agric. \& Environ. Sci. 4 (4): 417 426.

Abdel-Rahman, M.M.A. and A.E.M. Mansour (2015). Response of Williams plants to application of $\mathrm{EM}_{1}$ and yeast. Middle East J. of Agric., 4 (2): 277-282.

Abou-Zaid, M. (1984). Biochemical studies on fodder yeast. Ph.D. Thesis Fac. of Agric. Cairo Univ. Egypt.

Ahmed, F.F., A.M.M.A. Akl, and A.A.F. Oraby (2013). Partial replacement of inorganic nitrogen fertilizer by 
spraying some vitamin, yeast and seaweed extract in Ewaise mango orchard under upper Egypt conditions. Stem Cell 4(3): 1-13.

Ahmed, F.F.; A.S. Abdalla and A. M.T. Sabour (2003). Growth and fruiting of Williams banana as affected by some antioxidant and biofertilizer treatments. Minia J. Agric. Res. \& Develop., 24 (4): 580-600.

Alscher, R.G., J.L. Donahue and C.L. Cramer (1997). Reactive oxygen species and antioxidants: relationship in green cells. Physiol. Plant, 100: 224-233.

Badran, M.A.F. and Y.A. Mohamed (2009). Response of Williams banana plants to application of $\mathrm{EM}_{1}$ and yeast. Egypt J. Agric. Res. 87(1): 129-140.

Barnett, J.A.; R.W. Payne and D. Yarrow (1990). Yeast characteristics and identification. Cambridge Univ. Press, London pp. 999.

Ebrahiem, T.A., F.F. Ahmed and E.A. Abo El- Komsan (2000). Response of Balady mandarin trees grown in sandy soil to spraying active dry yeast and some macronutrients. Assiut J. Agric. Sci. 31(5): 200221.

Elade, Y. (1992). The use of antioxidant to control gray mould (Botrytic cinera) and white mould (Sclerotinia reletotiorum) in various crops. Plant Path. 141: 417-426

El-Baz, E.E.T.; L.A. Arafat; E.G. Ibrahim and M.R.L. El-Deeb (2016). Effect of cobalt and some vitamins as foliar application treatments on productivity and quality of Williams banana cultivar. J. Plant Production, Mansoura Univ., 7 (7): 777-786.

Gobara, A.A. (2004). Effect of Algae extract and yeast on fruiting of Zaghloul date palms. J. of Agric.
Sci. Mansoura Univ. 29(9): 52095220.

Gomez, K.A. and Gomez, A.A. (1984). Statistical Procedures for Agriculture Researches ( $2^{\text {nd }}$ ed.) Published by John Wiley and Sons, New York, U.S.A. p. 10-20.

Hewitt, C.W. (1955). Leaf analysis as a guide to the nutrition of banana. En. P. J. Exp. Agric., 23: 11.

Kuttimani, R.; K. Velayudham and E. Somasundaram (2013). Growth and yield parameters and nutrient uptake of banana as influenced by integrated nutrient management practices. Inter. J. of Recent Scientific Res., 4 (5): 680-686.

Mahmoud, Kh. M.H., (2012). Reducing inorganic $\mathrm{N}$ fertilizer in Balady mandarin orchard through application of extracts of yeast, seaweed and farmyard manure. M.Sc. Thesis Fac. of Agric. Minia Univ. Egypt.

M.A.L.R. (2016). Ministry of Agriculture and Land Reclamation Publishes Economic Affairs Sector.

Mead, R., R.N. Currnow and A.M. Harted (1993). Statistical Methods in Agricultural Biology. $2^{\text {nd }} \mathrm{Ed}$. Chapman \& Hall, London, pp: 5460.

Merwad, M.M.A. (2011). Effect of nitrogen sources, rates, some biostimulants and antioxidants on growth \& productivity of banana plants. Ph.D. Thesis Fac. of Agric. Zagazig Univ. Egypt.

Mostafa, E.A. (2004). Effect of spraying with ascorbic acid vitamin B and active dry yeast on growth, flowering, mineral status, yield and fruit quality of Grand Naine banana plants. Annals of Agric. Sci. 49 (2): 643-659.

Moustafa, M.F.A. and A.A. El- Hosseiny (2001). Influence of spraying active dry yeast solution on growth, yield, fruit quality and leaf NPK 
content of Washington Navel orange trees. J. Agric. Sci. Mansoura Univ. 26 (10): 6293-6305.

Murry, D.B. (1960). Deficiency symptoms of the major elements in the banana. Trop.Agric.Trim.36:100107.

Ragab, M.M. (2002). Effect of spraying urea, ascorbic acid and NAA on fruiting of Washington Navel orange trees. M.Sc. Thesis, Fac. Agric., Minia.

Roshdy, Kh.A. (2016). Effect of application of yeast and spraying with potassium and sulphur on growth and fruiting of Williams bananas. Egypt. J. Agric. Res., 94 (1): 105118.
Saleh, M.M.S. (1996). Effect of fertilization with different forms of nitrogen fertilizers on growth, flowering, mineral content and yield of banana. Ph.D. Thesis, Fac. Agric., Ain Shams Univ., Cairo, Egypt.

Samiullah, S.A., M.M. Ansari and R.K. Afridi, (1988). B- vitamins in relation to crop productivity. Ind. Res. Life Sci., 8: 51-74.

Wilde, S.A.; R.B. Cory; J.G. Layer and G.K. Voigt (1985). Soil and Plant Analysis for tree Culture Oxford and IBH publishing Co., New Delhi, India pp.94-105. 
تأثير إضافة الخميرة وحمض الأسكوربيك علي نمو و إثمار نباتات الموز الوليامز

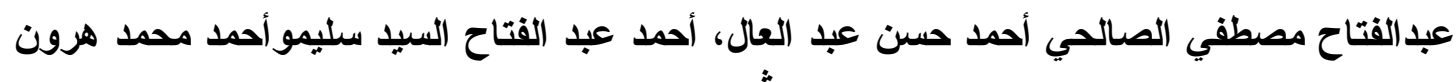

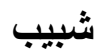

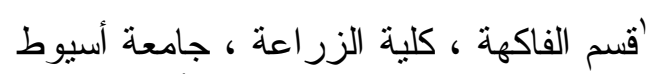

آقسم البساتين ، كلية الزر اعة، جامعة الأزهر ، فرعة أسيوط أسيوط

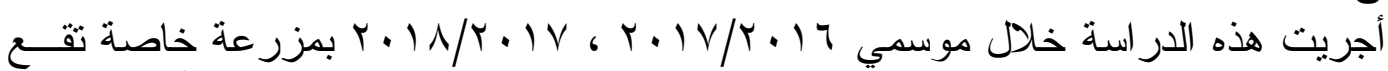

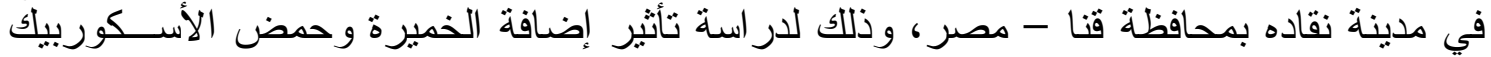

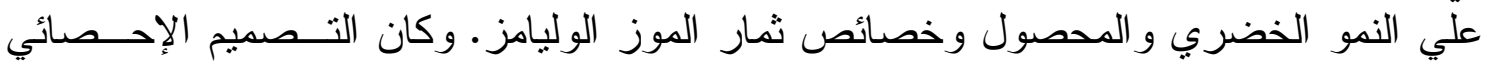
المستخدم هو القطاعات الكاملة العشو ائية ذو القطع المنشقة مرة واحدة العدة.

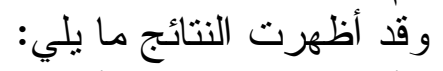

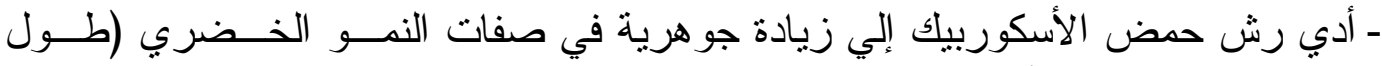

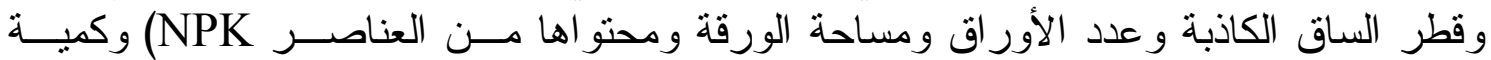

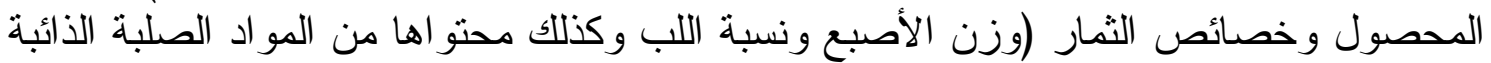

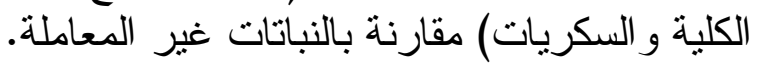

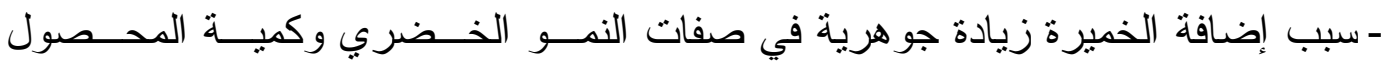
وخصائص الثمار مقارنة بعدم إضافة الخميرة.

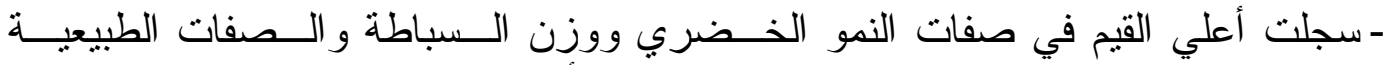

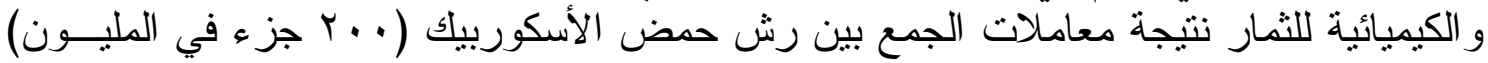

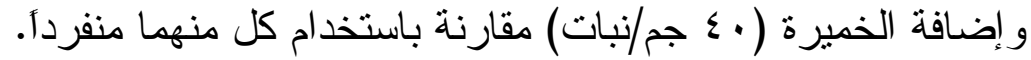

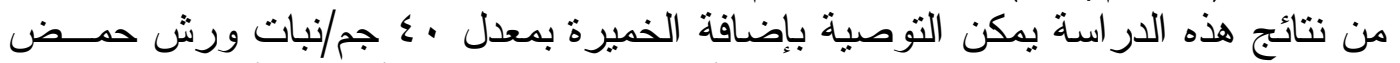

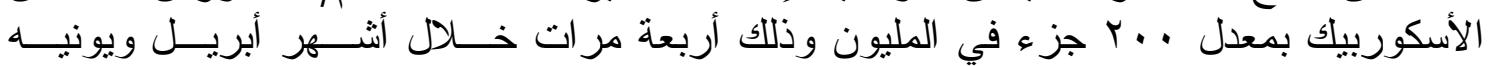

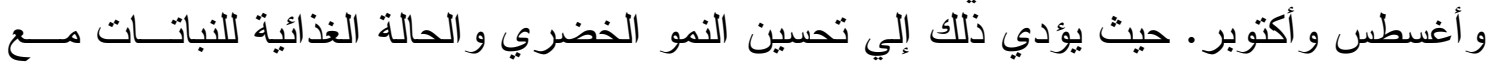
إنتاج محصول عال ذو خصائص ثرية جيدة. 